\title{
A morphological study of macrophage and synovial cell interactions with hydroxyapatite crystals
}

\author{
ROBERT S HIRSCH, KYM SMITH, AND BARRIE VERNON-ROBERTS \\ From the Department of Pathology, University of Adelaide, and the Division of Tissue Pathology, Institute of \\ Medical and Veterinary Science, Adelaide, South Australia
}

SUMMARY Hydroxyapatite crystals have been found in synovial fluids and periarticular spaces in association with osteoarthritis. This study examined the morphology of the interaction of macrophages and synovial cells with hydroxyapatite in order to determine the fate of hydroxyapatite over an extended culture period. Mouse peritoneal macrophages and bovine $e_{\infty}^{N}$ synovial cells were grown as monolayers. The morphology of the interaction between $\stackrel{+}{+}$ hydroxyapatite crystals (HAC) and these cells was studied by light microscopy, transmission and은 scanning electron microscopy for up to 14 days. Phagocytosis of HAC, phagosome formation, $\rightarrow$ and concentration of crystal aggregates around the cells began within four minutes of their

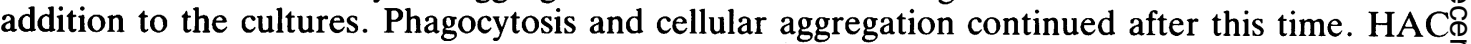
caused minimal cellular disruption despite the uptake of large amounts of crystalline material and ${ }_{0}^{3}$ significant cellular enlargement. HAC remained within cells for the duration of the study without ${ }^{\stackrel{D}{ }}$ any apparent dissolution by the cells. Whether macrophages are stimulated to produgec $\overrightarrow{0}$ interleukin I as a result of HAC uptake is currently under investigation.

Key words: crystals, phagocytosis, cell culture, ultrastructure.

Deposits of crystals within and around joints are well recorded as being associated with arthropathies such as gout and pseudogout. The most recent candidate for involvement in the osteoarthritic process, particularly in the joints of the shoulder, hip, and spine, is calcium hydroxyapatite. ${ }^{1}$ Crystals of hydroxyapatite (HAC) are found in synovial fluids sampled from patients with advanced osteoarthritis and unexplained joint swellings ${ }^{2}$ and in the 'Milwaukee shoulder' syndrome ${ }^{3}$ when sophisticated electron microscopic techniques are used. The source of the HAC in synovial fluids is thought to be deposits formed within biochemically compromised osteoarthritic cartilage, the calcification being initiated by matrix vesicles. ${ }^{4}$ Access to the synovial fluid may occur via cartilage fibrillation or as a consequence of abrasion of the surface of the cartilage in which HAC are embedded. Inside the joint space crystals are probably instantaneously covered with protein, since HAC avidly adsorb most proteins. ${ }^{5}$

Accepted for publication 10 May 1985.

Correspondence to $\mathrm{Dr} \mathrm{R}$ Hirsch, Department of Pathology, University of Adelaide, GPO Box 498, Adelaide 5001, South Australia.
Clearance of the crystals may occur through uptake by type A synovial cells, as has been showre for calcium pyrophosphate dihydrate and other calcium phosphate crystals in human and rabbi joints. ${ }^{6}$ Clearance of the particulate material may also occur by its phagocytosis by neutrophils of macrophages chemotactically attracted to the synovial space from the peripheral circulation. Products of the ingestive and degradative activity of the cells on the crystals may have an important role in the pathogenesis of the osteoarthritic process associated with HAC. Jasin and Dingle ${ }^{7}$ have suggested that activated human mononuclear cells may produceo 'catabolite' which mediates cartilage matrix de gradation through chondrocyte activation.

Little information is available about the nature of the interaction of polymorphonuclear cells (PMN) and macrophages with $\mathrm{HAC}$ and other crystals $\sigma$ Human PMN were exposed to commercially obtained HAC $(0.4-15 \mu \mathrm{m})$ for up to 120 minutes by Maurer and Schumacher. ${ }^{8}$ Endocytosis of HAC an£ degranulation of PMN occurred three minutes after mixing cells and crystals. After 120 minutes $35 \%$ of PMN were necrotic compared with $19 \%$ in contro 
suspensions. Monocytes and eosinophils that were also present in the PMN suspension had endocytosed HAC but did not become necrotic.

Dieppe et al. ${ }^{9}$ also found that HAC were toxic to $\mathrm{PMN}$, initiating the release of more $\beta$-glucuronidase than a similar quantity of monosodium urate crystals. Radiolabelled synthetic HAC crystals were avidly phagocytosed by unstimulated mouse peritoneal macrophages. ${ }^{10}$ In the present morphological study the interaction of murine macrophages and bovine synovial fibroblasts with HAC was investigated by phase contrast light microscopy, transmission electron microscopy (TEM), and scanning electron microscopy (SEM).

\section{Materials and methods}

\section{MACROPHAGE CULTURES}

Peritoneal washouts from male C57 mice were obtained 24 hours after the intraperitoneal injection of $1 \mathrm{ml}$ of $10 \%$ sterile protease peptone (Difco, Detroit, Michigan, USA). The cell suspension was centrifuged at $800 \mathrm{rpm}$ for 20 minutes at $4^{\circ} \mathrm{C}$, and the pellet was resuspended in RPMI 1640 tissue culture medium supplemented with $10 \%$ fetal calf serum (FCS) and penicillin/streptomycin. The cells were diluted to a final concentration of $2 \times 10^{6} / \mathrm{ml}(2$ $\left.\times 10^{9} / 1\right)$ and $1 \mathrm{ml}$ of cell suspension was added to the wells of Costar $16 \mathrm{~mm}$ tissue culture plates. Sterile Millipore filters (type HATF, $13 \mathrm{~mm}$, pore size 0.45 $\mu \mathrm{m})$ soaked in supplemented RPMI had been placed in half of the wells. The plates were incubated in a humidified atmosphere of $5 \%$ carbon dioxide and air at $37^{\circ} \mathrm{C}$ for one hour. Each well was then washed four times with Dulbecco's salt solution to remove non-adherent cells. Non-specific esterase staining of cells in four wells indicated that $90 \%$ of the cells were macrophages. After incubation for a further period of 24 hours fresh medium containing $120 \mu \mathrm{g}$ of HAC was added. The HAC were prepared from the Sigma Chemical Co. (St Louis, Missouri, USA) type 1 No HO252 hydroxyapatite. Particles in the size range $0.4-3 \mu \mathrm{m}$ were prepared by overnight sedimentation of Sigma HAC in the presence of $5 \%$ FCS. The smallest particles remained in suspension and were subsequently centrifuged, washed, and dried.

SYNOVIAL CELL CULTURES

A forelimb of a freshly slaughtered calf was obtained from the South Australian Meat Corporation, and synovial cells were harvested from the metacarpophalangeal joint by trypsinisation. ${ }^{11}$ The cell suspension was centrifuged and the pellet resuspended in supplemented RPMI 1640. The cells were incubated at $37^{\circ} \mathrm{C}$ in $25 \mathrm{ml}$ Corning tissue culture flasks until the cells were confluent (7-10 days) and subcultured for use in microcrystal interaction studies after three passages. Cells were detached from the culture flasks with trypsin suspended in fresh medium and plated into Costar 16 $\mathrm{mm}$ tissue culture wells. Approximately $1 \times 10^{6}$ cells were added to each well. Crystals were added (as in the macrophage cultures) when the cells were $90 \%$ confluent.

\section{IGHT MICROSCOPY}

Cultures of cells with and without crystals were examined by phase contrast light microscopy and photomicrographs taken with Kodak Technical Pan film at four, 20, 24, and 50 hours, and seven, nine, and 14 days for both cultures.

\section{ELECTRON MICROSCOPY}

Cultures on Millipore filters were used for scanning and transmission electron microscopy (SEM and TEM). For TEM filters were fixed in $2.5 \%$ cacodylate-buffered glutaraldehyde for two hours at room temperature at four, 10, 60 minutes, and 24 and 48 hours after the addition of crystals. The filters were then postfixed in $2 \%$ osmium tetroxide for one hour, dehydrated through graded ethanols, and embedded in epoxy embedding resin. Transverse sections of the filters were cut and stained with uranyl acetate and lead citrate.

For SEM filters were fixed at 24 hours in glutaraldehyde (as above), dehydrated through ethanol, and critically point dried with carbon dioxide as the transitional fluid. The filters were then attached to copper stubs with silver dag and coated with carbon and gold. Specimens were examined by JEOL $100 \mathrm{CX}$ TEMSCAN and JEOL JSM P15 microscopes.

\section{Results}

PHASE CONTRAST LIGHT MICROSCOPY Control macrophage cultures

Macrophages were present initially as a dense monolayer. With the passage of time the cell density decreased, but the macrophages retained a plump, healthy appearance.

\section{Macrophages and $H A C$}

Four minutes after addition of HAC small clear zones around the cells indicated that cellular uptake of the particles was in progress. HAC were evenly distributed over the floor of wells containing medium but no cells, confirming that the clearing effect was associated with uptake of HAC. After four hours the macrophages had taken up most of the HAC and the cells became rounded. After 24 


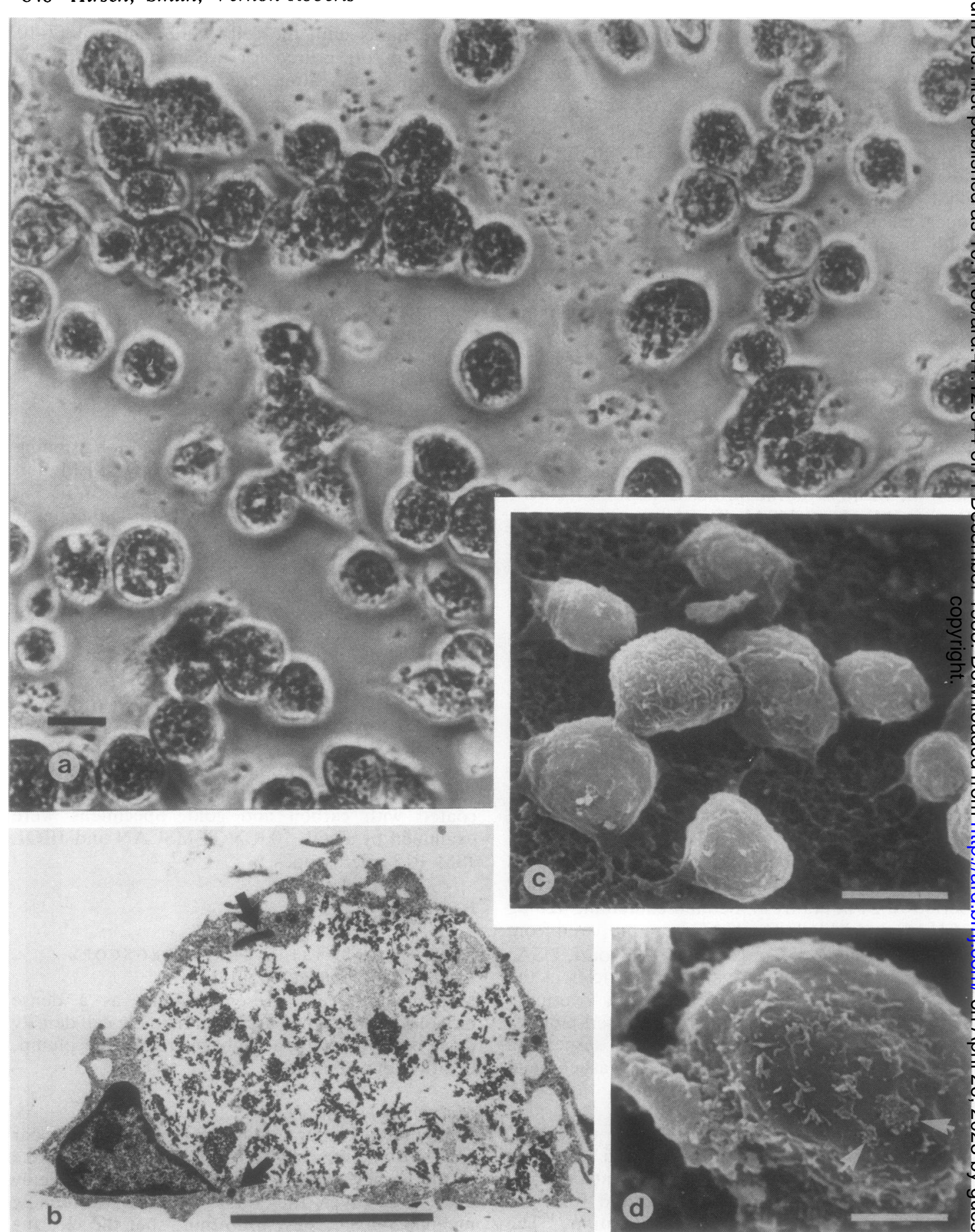

Fig. 1 Macrophages 24 hours after the addition of HAC. (a) Phase contrast micrograph showing rounding of macrophages and cellular uptake of large quantities of HAC. Bar=15 $\mu \mathrm{m}$. (b) Transmission electron micrograph (TEM). The cytoplasm contains large phagolysosomes with HAC. Few primary lysosomes are present (arrows). Bar $=5 \mu \mathrm{m}$. (c) Scanning electron micrograph (SEM). The cells are rounded and have few cytoplasmic processes and attachments to the substrate. Bar $=15 \mu \mathrm{m}$. (d) SEM. HAC aggregates are attached to the cell surface (arrows), which is relatively smooth. $B a r=5 \mu m$. 
hours the cells were less numerous; those remaining were engorged with particulate material (Fig. 1a), and the cells were aggregated in clusters. After five days cell clustering persisted and particulate material was still visible in the cells' cytoplasm. After nine and 14 days occasional focal deposits of particulate material were surrounded by clusters of cells.

\section{Control synovial cultures}

Synovial cells resembled fibroblasts, being well spread with cytoplasmic processes interconnecting with those of neighbouring cells. With the passage of time considerable cell division had occurred and the cells formed a reticular pattern.

\section{Synovial cells and $H A C$}

Uptake of HAC was noticeable four hours after addition, and by 24 hours most of the HAC was intracellular. At seven days the cells were densely packed and particulate material was localised in intracellular vacuoles.

\section{TRANSMISSION ELECTRON MICROSCOPY} Macrophage cultures

At the time of addition of the crystals the surface of the filters was densely populated by macrophages, with cell processes extending a short distance into the filter. Cells which were directly in contact with the filter were elongated. Lysosomes were prominent in all cells (Fig. 2a).

Cells had endocytosed small aggregates of HAC after four minutes. The crystals were contained in membrane bound phagosomes (Fig. 3). After 60 minutes few primary lysosomes were seen in the cells. At 24 hours the cells had endocytosed large amounts of HAC and most of the cytoplasm had become a phagosome (Figs $1 \mathrm{~b}$ and $\mathrm{c}$ ). After two days much of the HAC had disaggregated but the cells were still intact and attached to the filter.

\section{Synovial cells}

Synovial cells grown on Millipore filters did not show the same degree of confluency as cells grown on plastic. The control cells were spindle shaped with eccentric ovoid nuclei (Fig. 4). Some cell processes extended a short distance into the filter. The cells had begun to endocytose the HAC crystals by surrounding them with pseudopods after only 10 minutes. At 60 minutes the cells contained large amounts of HAC enclosed within membrane bound vacuoles. After seven days the cells were still intact and contained large quantities of particulate material (Fig. 5).

\section{SCANNING ELECTRON MICROSCOPY \\ Macrophage cultures}

The control cells had a flattened appearance except
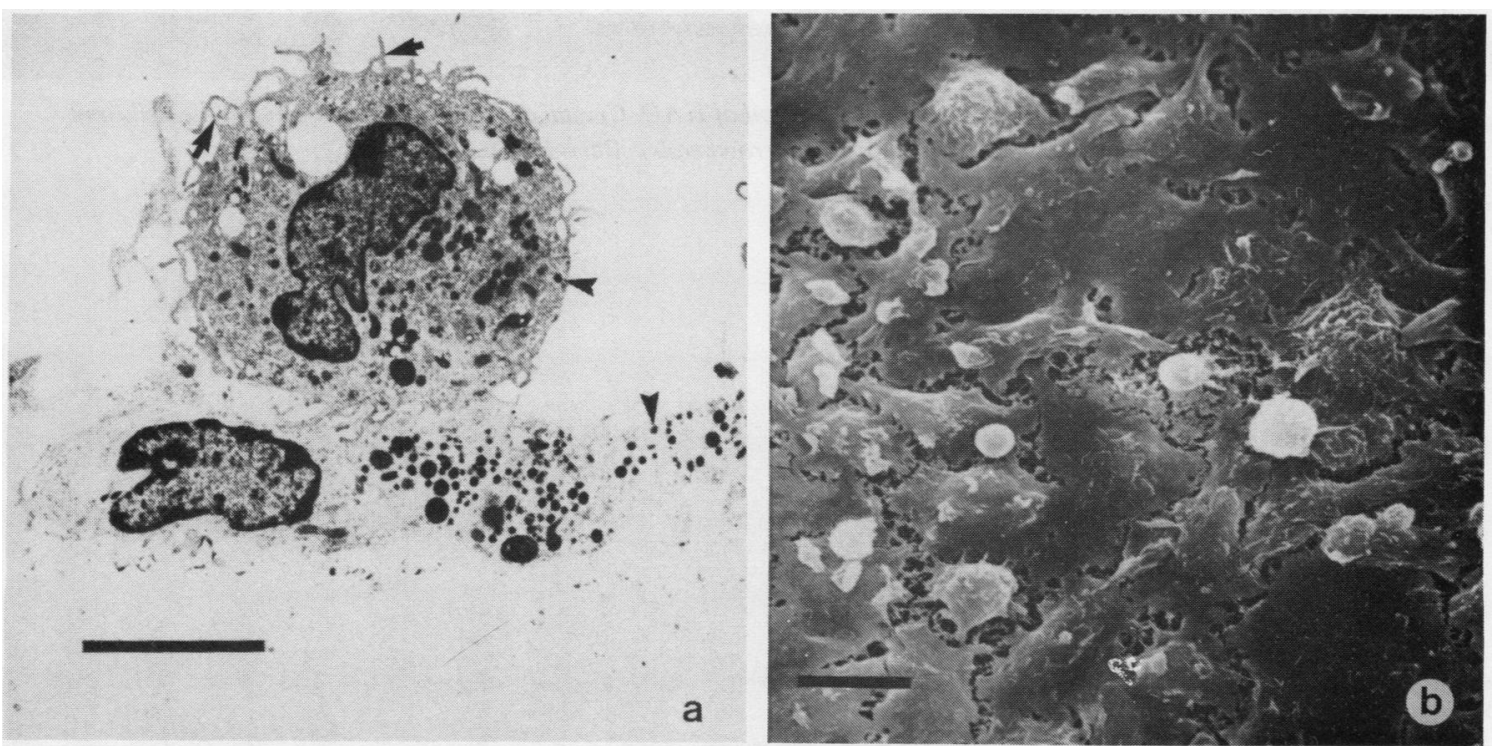

Fig. 2 Control macrophages. (a) TEM. The bottom cell which is attached to the substrate is elongated (flattened) in shape.

The top cell is rounded but shows extensive cell processes (arrow's). Both cells contain numerous primary lysosomes (arrowheads). Bar=5 $\mu \mathrm{m}$. (b) SEM. The cells are flattened and well spread on the substrate. A few rounded cells are present. Bar $=15 \mu \mathrm{m}$. 
848 Hirsch, Smith, Vernon-Roberts

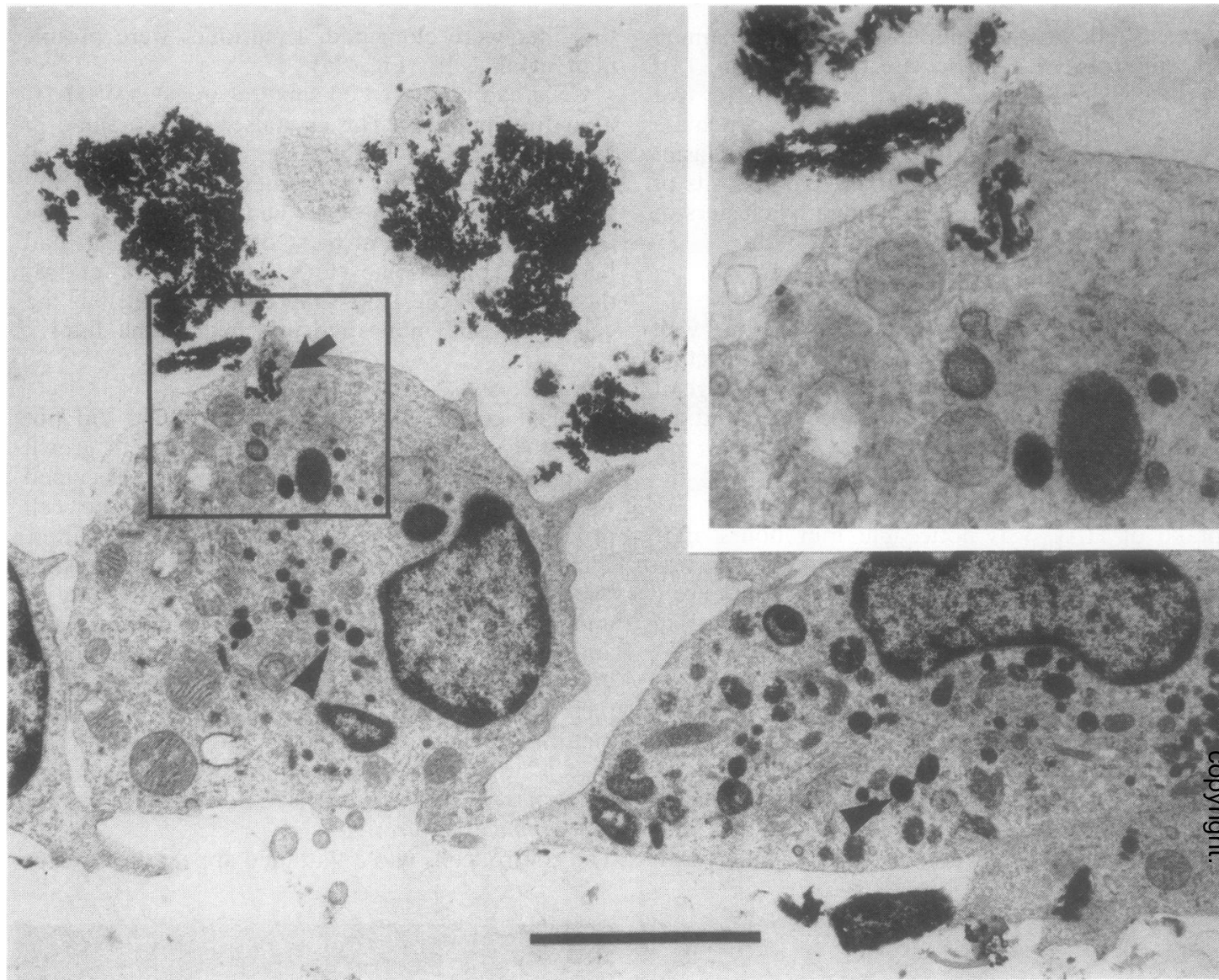

Fig. 3 TEM of macrophages four minutes after the addition of HAC. Crystal aggregates are seen around the cells and phagocytosed (arrow). Primary lysosomes are abundant (arrowheads). Bar $=15 \mu \mathrm{m}$.

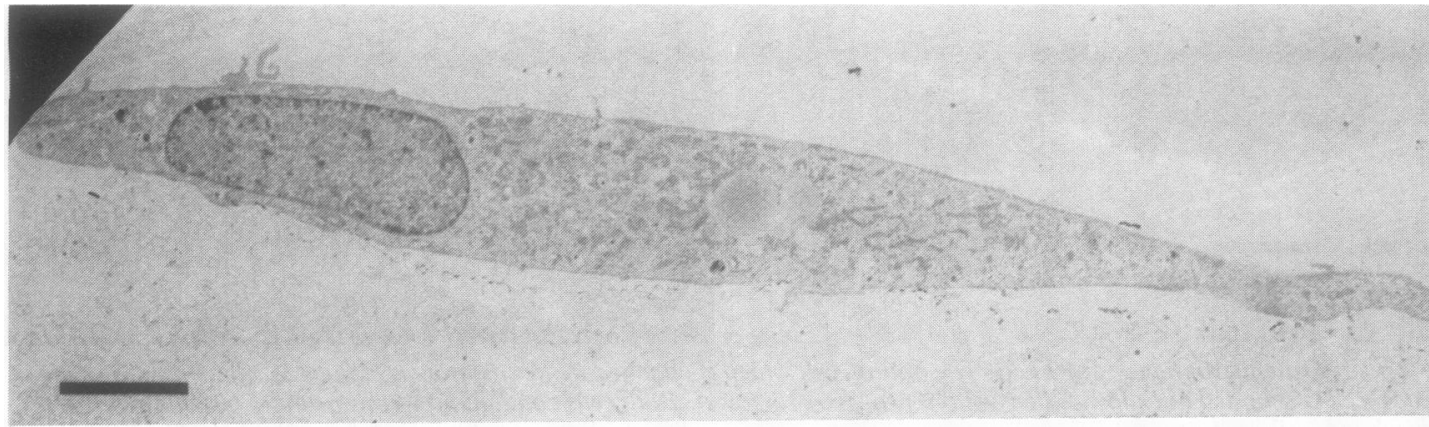

Fig. 4 TEM of a control synovial cell. Bar $=5 \mu \mathrm{m}$. 


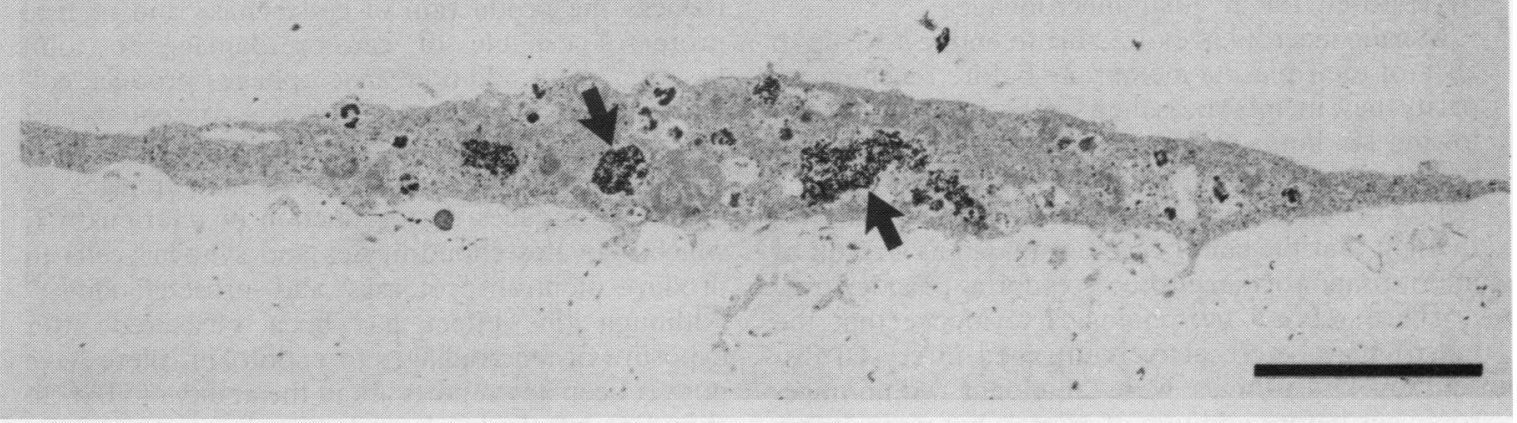

Fig. 5 TEM of a portion of a synovial cell seven days after the addition of HAC. Crystal aggregates are present in phagolysosomes (arrows). Bar $=5 \mu \mathrm{m}$.

for some rounded cells that were not in contact with the substrate (Fig. 2b). After 24 hours the cells that had been exposed to HAC were rounded and covered less of the filter surface (Figs $1 c$ and d). Thin filopodia were still attached to the filter. Cell processes and crystalline material were present on the cell surfaces.

\section{Discussion}

The removal of hydroxyapatite crystals from the synovial fluid of sufferers of apatite-associated arthritis is accomplished predominantly by macrophages (derived from the peripheral circulation) and by type A synovial cells. ${ }^{12} 13$ It was therefore of interest to investigate the interaction of HAC and macrophages in a controlled environment.

Murine peritoneal macrophages were chosen as the source of mononuclear cells because of their ready availability and use in previous studies of macrophage/bone powder interactions. ${ }^{10} 1415$ Millipore filters are widely used as in-vitro cell supports and are ideal for use in ultrastructural cell studies, since they are not affected by the solutions used in processing. ${ }^{16}$

Macrophages are very responsive to environmental changes, and tissue culture conditions are artificial. The cells attempt to endocytose the substrate on which they are grown. ${ }^{17}$ This is illustrated by the cytoplasmic spreading of cells in contact with the filters, whereas the cells on top of those were rounded in shape. Synovial cells in culture show extensive morphological alterations, ${ }^{18}$ and special culture conditions are required to maintain the type $\mathrm{A}$ and $\mathrm{B}$ cells. ${ }^{19}$ Since these conditions were not adhered to, it is likely that the synovial cells grown were essentially fibroblastic.
The appearance of the control macrophages examined 24 hours after seeding into the wells was characteristic of macrophages in culture as described by Adams. ${ }^{20}$ With the passage of time the numbers of cells decreased. This phenomenon reflected the heterogeneity of the macrophage population with varying degrees of attachment capability and ability to survive in vitro.

The concentration of HAC added to each well $(120 \mu \mathrm{g})$ was similar to that used by Cheung et al. ${ }^{25}$ who studied the mitogenic effect of HAC on synovial cells grown in similarly sized wells. The quantity of HAC used did not appear to cause overloading of the cells and was sufficient to carpet the floor of the wells evenly.

Precoating of the HAC with protein adsorbed during the crystal sizing procedure was not considered to have influenced the nature of the cell/ crystal interaction, since the experiments were all carried out in the presence of $10 \%$ FCS. It is not known whether proteins adsorbed by the crystals were denatured during drying; however, there was no clear evidence of protein coating in the TEM sections.

The light microscopic, TEM, and SEM appearance of cell cultures to which small HAC aggregates had been added showed the rapid uptake of large quantities of crystals. Although the number of cells decreased with time, no free crystals were observed around the remaining cells, indicating that crystals released from necrotic cells had been endocytosed by the remaining cells. In general, it appeared that only the cells that had endocytosed very large amounts of crystals were damaged.

The avidity and rate at which the macrophages endocytosed the particulate materials added to the cultures corresponded to the findings of a previous 
study $^{21}$ where quartz particles $(1-3 \mu \mathrm{m}, 100 \mu \mathrm{g} / \mathrm{ml}$ $(\mathrm{mg} / \mathrm{l})$ ) were endocytosed within two to four minutes by cultured rat alveolar macrophages.

Murine macrophages are able to endocytose up to $50 \%$ of their plasma membrane before reaching capacity; new membrane is then synthesised over the following six hours. ${ }^{22}$ The rounding of the cells that occurred after uptake of HAC is consistent with the uptake of milled metal particles by similar cells. ${ }^{23}$ It was thought that the cells became rounded as a result of interiorisation of the cell processes during phagocytosis.

There was no morphological evidence that the macrophages were actively engaged in crystal dissolution. Lysosomes were abundant within macrophages before addition of crystals but were sparse at subsequent times. The disappearance of the lysosomes may have occurred as a result of 'regurgitation' during crystal endocytosis or discharge into the phagosomes. Synthesis of new lysosomes may have been wholly or partially inhibited by the presence of large quantities of crystals that occupied the bulk of the cells' cytoplasm.

Murine macrophages are known to dissolve calcium from radiolabelled bone powder by contact dependent resorption; ${ }^{14}$ isotope release occurs rapidly and continues in a linear fashion for at least 48 hours. ${ }^{15}$ Recently, canine synovial cells have been shown to dissolve HAC in vitro, ${ }^{24}$ presumably as a result of phagolysosomal activity, but release of dissolved calcium was studied for only 45 hours. The same workers reported that, per milligram of cell protein, cultured human monocytes were 30 times more potent solubilisers of $\left[{ }^{45} \mathrm{Ca}\right] \mathrm{HAC}$ than cultured canine synovial cells or human fibroblasts. The results of the present morphological study indicated that early discharge of lysosomes occurs after phagocytosis, and in longer term cultures endocytosed HAC remain in the cells without attracting a phagolysosomal response or resulting in cellular damage.

The sparsity of synovial cells grown on Millipore filters suggested that this surface was not as conducive to cell proliferation as was the plastic surface of the culture wells. Synovial cells were actively phagocytic, and uptake of HAC occurred within a similar time scale as for the macrophages. The cells remained viable over the 14 -day period but, since cell numbers were not quantified, the mitogenic effect of the HAC could not be assessed.

Various mechanisms for the participation of HAC in the pathogenesis of osteoarthritis (OA) have been suggested. Endocytosis of HAC by synovial cells and foreskin fibroblasts in vitro has been shown to stimulate cell division, ${ }^{25}$ possibly as a result of raised intracellular calcium ion concentrations. The synovial thickening observed in $\mathrm{OA}$ may reflect this mitogenic action. Direct exposure of synovial cells fibroblasts, and chondrocytes to HAC in vitro. induces the production of collagenase and neutrali proteases capable of causing damage to join tissues. ${ }^{26}{ }^{27}$ In addition, macrophages produce cote lagenase and neutral proteases as a consequence of the phagocytosis of inert particles such as late spheres. ${ }^{28}$ Finally, stimulation of macrophages $b \vec{B}$ endotoxin induces the production of interleukin Iy which activates chondrocytes and synovial cells to produce neutral proteases and prostaglandins. $\stackrel{2 \oplus}{.}$ Although this effect has been measured afte exposure of macrophages to endotoxin, there have not yet been any reports about the ability of HAC t\& stimulate interleukin I production by macrophages We are in the process of investigating the interactiont of HAC stimulated macrophage products withu fibroblasts, synovial cells, and chondrocytes in ordeg to elucidate further the roles of HAC and othef crystals in crystal associated arthropathies.

This study was supported by grants from the NH and MRC and the Australian Rheumatism Association (SA branch). Mr D Caville thanked for preparing the photographs.

\section{References}

1 Dieppe P A, Calvert P. Crystals and joint disease. Lon\& $\overbrace{0}$ Chapman \& Hall, 1983: 5.

2 Dieppe P A. Crystal deposition and inflammation. $Q J$ New Series III 1984: 309-16.

3 McCarty D J, Halverson P B, Carrera G F, Brewer B J, Kozi F. 'Milwaukee shoulder' - association of microspheroids con taining hydroxyapatite crystals, active collagenase, and neutrat protease with rotator cuff defects. I. Clinical aspects. Arthrit क्षे Rheum 1981; 24: 464-73.

4 Ali S Y. Mineral-containing matrix vesicles in human osteoa throtic cartilage. In: Nuki G, ed. Aetiopathogenesis of osteoa? throsis. London: Pitman Medical, 1980: 105-16.

5 Glueckhauf E, Patterson L. The adsorption of some proteins of hydroxyapatite and other adsorbents used for chromatic separ tions. Biochim Biophys Acta 1974; 351: 57-76.

6 Palmer D W, McCarty D J. Clearance of ${ }^{85}$ Ca-labeled calcium phosphate crystals from rabbit joints. Arthritis Rheum 1984; $2 \%$ 427-32.

7 Jasin H E, Dingle J T. Human mononuclear cell factors mediacr. cartilage degradation through chondrocyte activation. $J$ Cl@ Invest 1981; 68: 571-81.

8 Maurer K H, Schumacher H R. Hydroxyapatite phagocytosis by human polymorphonculear leucocytes. Ann Rheum Dto 1979; 38: 84-8.

9 Dieppe P A, Hornby J, Swan A. Different effects of crystals oi release of inflammatory mediators from human peripherât blood phagocytic cells. Ann Rheum Dis 1983; 42 (suppl): 112

10 Chambers T J. Diphosphonates inhibit bone resorption by macrophages in vitro. J Pathol 1980; 132: 255-62.

11 Fraser J R E, McCall J F. Culture of synovial cells in vitrô Notes on isolation and propagation. Ann Rheum Dis 1965; 24. 351-9.

12 Schumacher H R, Cherian P V, Reginato A J, Bardin Rothfuss S. Intra-articular apatite crystal deposition. An Rheum Dis 1983; 42: (suppl): 54-9.

13 Garancis J C, Cheung H S, Halverson P B, McCarty D I 'Milwaukee shoulder' - association of microspheroids contaim ing hydroxyapatite crystals, active collagenase, and neutro 
protease with rotator cuff defects. III. Morphologic and biochemical studies of an excised synovium showing chondromatosis. Arthritis Rheum 1981; 24: 484-91.

14 Chambers T J. Resorption of bone by mouse peritoneal macrophages. J Pathol 1981: 135: 295-9.

15 Teitelbaum S L, Stewart C C. Kahn A J. Rodent peritoneal macrophages as bone resorbing cells. Calcif Tissue Int 1979; 27: 255-61.

16 McCombs R M, Benyesh-Melnick M. Brunschwig J P. The use of millipore filters in ultrastructural studies of cell cultures and viruses. J Cell Biol 1968; 36: 231-43.

17 Meltzer M S. Peritoneal mononuclear phagocytes from small animals. In: Adams D O, Edelson P J, Koren H S, eds. Method for studying mononuclear phagocytes. New York: Academic Press, 1981: 63-7.

18 Glen-Bott A M. Ultrastructure of synovial cells in vitro. Ann Rheum Dis 1972; 31: 207-14.

19 Clarris B J, Fraser J R E, Moran C J, Muirden K D. Rheumatoid synovial cells from intact joints. Morphology, growth and polykaryocytosis. Ann Rheum Dis 1977; 36: 293-301.

20 Adams D O. Macrophages. In: Jakoby W B, Pastan I H, eds. Cell Culture. New York: Academic Press, 1979: 494-506. (Jakoby W B, Pastan I H, eds. Methods in enzymology; vol 58).

21 Miller K M, Handfield R I M, Kagan E. The effect of different mineral dusts on the mechanisms of phagocytosis: a scanning electron microscope study. Environ Res 1978; 15: 139-54.

22 Werb Z, Cohn Z A. Plasma membrane synthesis in the macrophage following phagocytosis of polystyrene latex particles. J Biol Chem 1972; 247: 2439-46.

23 Garrett R, Wilksch J, Vernon-Roberts B. Effects of cobaltchrome alloy wear particles on the morphology, viability and phagocytic activity of murine macrophages in vitro. Aust J Exp Biol Med Sci 1983; 61: 355-69.

24 Evans R W, Cheung H S, McCarty D J. Cultured canine synovial cells solubilize ${ }^{45} \mathrm{Ca}$-labeled hydroxyapatite crystals. Arthritis Rheum 1984: 27: 829-32.

25 Cheung H S, Story M T, McCarty D J. Mitogenic effects of hydroxyapatite and calcium pyrophosphate dihydrate crystals on cultured mammalian cells. Arthritis Rheum 1984; 27: 668-74.

26 Cheung H S, Halverson P B, McCarty D J. Release of collagenase, neutral protease, and prostaglandins from cultured mammalian synovial cells by hydroxyapatite and calcium pyrophosphate dihydrate crystals. Arthritis Rheum 1981; 24: 1338-44.

27 Cheung H S, Halverson P B, McCarty D J. Phagocytosis of hydroxyapatite or calcium pyrophosphate dihydrate crystals by rabbit articular chondrocytes stimulates release of collagenase, neutral protease, and prg E2 and F2a(41628). Proc Soc Exp Biol Med 1983; 173: 181-9.

28 Werb Z, Reynolds J J. Stimulation by endocytosis of the secretion of collagenase and neutral proteinase from rabbit synovial fibroblasts. J Exp Med 1974; 140: 1482-97.

29 McGuire-Goldring M B, Meats J E, Wood D D, Ihrie E J, Ebsworth N M, Russell R G G. In vitro activation of human chondrocytes and synoviocytes by a human interlcukin I like factor. Arthritis Rheum 1984; 27: 654-62. 